\title{
The Effectiveness of Teaching Critical Thinking Skills through Literature in EFL Context: A Case Study in Spain
}

\author{
Svetlana Stefanova (Corresponding author) \\ Department of English and English Language Didactics, International University of La Rioja, Madrid, Spain \\ E-mail: svetlana.stefanova@unir.net
}

\author{
Jelena Bobkina \\ Department of Linguistics Applied to Science and Technology, ETS Industrial Engineering, Technical University of Madrid, Madrid, Spain \\ E-mail: jelena.bobkina@upm.es
}

Francisco Javier Sánchez-Verdejo Pérez

Department of English and English Language Didactics, National University of Distance Education, Madrid, Spain

E-mail: fjsanchezverdejo@valdepenas.uned.es

Received: 11-04-2017

Published: 01-11-2017
Accepted: 14-06-2017

doi:10.7575/aiac.ijalel.v.6n.6p.252
Advance Access Published: September 2017

URL: http://dx.doi.org/10.7575/aiac.ijalel.v.6n.6p.252

\begin{abstract}
The present study investigates the effectiveness of teaching critical thinking skills through literary texts in the EFL classroom, based on the combination of reader-centered critical reading and critical literacy pedagogy. Our proposal seeks to address both language teaching and literacy education from a transnational perspective by dealing with critical thinking skills as a set of processes whose main aspects include the interpretation of the world, self-reflection, intercultural awareness, critical awareness, problem-solving, and language use. For the purpose of this study, a series of activities based on Caryl Phillips's novel The Lost Child (2015) have been designed, following the four curricular components of Multiliteracies pedagogy (Kalantzis \& Cope, 2000). Conducted in an EFL classroom in Spain, the study aims to validate the model of teaching critical skills built on working with current social issues, such as immigration, discrimination, and bullying. To evaluate the effectiveness of the model, teacher assessment and self-assessment questionnaires have been completed by the teacher and the students, respectively. A close analysis of the results reveals that both students and their teacher perceive the model as highly effective, in particular, in terms of self-reflection. Additionally, intrinsically motivating activities and frequent opportunities to discuss literary texts and relate them to current issues have proved to be highly beneficial for the students, providing them with a broader perspective that helps them interpret real-world problems properly. The assessment grid has proved effective, although for a wider application of the grid, the descriptors might have to be adapted to the students' age.
\end{abstract}

Keywords: critical thinking skills, critical literacy approach, literature, EFL classroom

\section{Introduction}

There is no doubt that the ability to think critically is one of the primary goals of education in the 21 st century that has direct connection with language teaching and learning as well as with our daily life. Since 1990, teachers have increasingly realised the necessity of developing students' ability to think critically both in higher education and in university EFL courses. Not surprisingly, over the past decades, numerous scholars and educators have advocated the necessity of teaching critical thinking as one of the essential skills in order to help students to operate effectively within society, make better judgments, and take personal, business or leadership decisions (Braun, 2004; Fisher, 2001; Kalyczynski, 2001; Willingham, 2007).

The EFL classroom provides multiple opportunities for teachers to enhance the development of students' thinking skills through a combination of teaching factual content and using this material critically (Khatib, Marefat \& Ahmadi, 2012; Moreno-Lopéz, 2004; Quing, 2013). According to Willingham (2007), one may teach students how to think, but without giving them the necessary background and knowledge, they will not be able to analyse the content properly. Thus, it becomes clear that the development of critical thinking skills is closely related to knowledge acquisition, as fostering students' active thinking and independent thinking ability helps them to put their previously acquired knowledge into practice.

Nonetheless, critical thinking is not given enough attention in the English classroom, which still focuses mostly on skill practice, vocabulary learning, and accumulation of linguistic structures (Bahadur Rana, 2012; Pineda Báez, 2004; Qing, 2013). We strongly believe that in the context of EFL teaching, the role of the teachers should not be restricted to the training of language skills, but they should also encourage students to reflect actively on social issues and current affairs, inspiring them to become agents of change. In a word, in order to be proficient language users, students need to 
know how to use critical thinking skills through the target language. One way to accomplish it is through reading and interpreting literary texts in the English language classroom, hence our study aims at analysing the effectiveness of teaching critical thinking skills through literary texts in the EFL context.

\section{Literature as a means of teaching critical thinking skills}

The use of literature in the EFL classroom has seen a revival during the last few decades. In explaining the benefits of integrating literature in the language classroom, scholars point to the value of the literary text as an effective stimulus for students to think critically and express their feelings and ideas in a non-native language. The benefits of literature for developing students' critical thinking skills and creativity have been highlighted by a number of researches (Alvarez, Calvete, \& Sarasa, 2012; Bobkina \& Dominguez, 2014; Bobkina \& Stefanova, 2016; Fernandez de Caleya, Bobkina \& Sarto, 2012; Ghosn, 2002; Sivasubramaniam, 2006; Van, 2009; Yaqoob, 2011). Thus, according to Lazere (1987), literature is an academic subject that "can come closest to encompassing the full range of mental traits currently considered to comprise critical thinking" (p. 3). It helps students to question and explore the world around them and opens "horizons of possibility" (Langer, 1997, p. 607). Along the same line, Ghosn (2002) affirms that literature brings changes into students' attitudes towards the world.

What's more, recent studies in this field have pointed to the possibility of engaging students into the process of joint meaning construction, assigning the reader an active role in meaning-making (Egan, 2005; Guerin, Labor, Morgan, Reesman, \& Willingham, 2005; Yaqoob, 2011). A close reading of a literary work can develop the skills students need to understand hidden meanings, reconstruct images from details, separate facts from opinions, examine phenomena from multiple points of view, and apply what they have learnt to other aspects of their daily life. In short, a close reading of a literary text involves all those skills that are part of the critical thinking process: analysis, synthesis, argumentation, interpretation, evaluation, problem-solving, and reasoning, among others (Brunt, 2005; Facione, 2007). In this way, the reader-response approach, which posits the active role of the reader, encourages students to generate and communicate their own interpretation of a literary text.

The advocates of teaching critical thinking skills to EFL learners often insist on the relation between language and social changes. Not surprisingly, critical thinking skills are frequently dealt with from ideological perspective. This perspective has recently been supported by those scholars who argue for the need of introducing critical literacy pedagogy into the classroom curriculum as a means of combating poverty, inequality and social injustice (Crookes, 2010; Curtis \& Romney, 2006; Nelson, 2008; Norton \& Toohey, 2004; Riasati \& Mollaei, 2012). These viewpoint is becoming especially relevant in the present due to persistent racial inequality and other forms of discrimination and exclusion at a global level.

Taking its roots in the socio-cultural view of the language, critical philosophy, pedagogy, feminist concerns, and postconstructivist theory, the critical literacy approach implies teaching students to read texts in an active, reflective way for a better understanding of those issues related to social injustice and inequality (Gee, 1996; Janks 2010; Van, 2009). Though rooted in various theories, it is most strongly associated to the critical pedagogy philosophy developed by the Brazilian educator Paulo Freire and is based on problem-posing education, that aims at making students critical thinkers. When applied through the paradigm of postmodern, poststructuralist, or feminist discourses, it encourages "teachers and students to engage in dialogues over texts that were meaningful in their lives" (Moreno-López, 2004, p. $81)$.

While critical literacy pedagogy is a relatively old concept, its application to EFL teaching is a rather new phenomenon that came to life in 1990s and was adopted by teachers in both mainstream English classrooms and EFL classrooms (Wallace, 1995). Since then, a significant number of scholars and educators have argued for the examination of the language curriculum and its re-organisation along critical pedagogy lines (Aliakbari \& Faraji, 2011; Benesh, 2009; Degener, 2001; Duncan-Andrade \& Morrell, 2008; Izadinia, 2011; Norton \& Toohey, 2004; Pennycook, 2001).

Thus, Riasati \& Mollaei (2012) affirm that when applied to language teaching, this approach adds to the critical quality of the current textbooks and overall language instruction. Taken into consideration the social nature of the language discourse, critical literacy pedagogy helps students to interpret the texts they read, questioning the social theories they relate to. What's more, both language learning and language teaching are viewed as ideologically driven processes that are at the heart of the educational curriculum (Norton \&Toohey, 2004). There is also a strong belief that the language curriculum should be designed taking into consideration students' personal experiences and realities (Ohara, Saft, \& Crookes, 2001).

To deal with literary texts in EFL classroom effectively, Bobkina \& Stefanova (2016) suggest a model that is based on the strategies endorsed by both the reader-centered critical reading approach and the critical pedagogy approach. For them, critical thinking skills required to work with literary texts in the EFL classroom "can be broadly defined as a set of processes whose main dimensions include the interpretation of the world, self-reflection, intercultural awareness, critical awareness, reasoning and problem-solving, and language use" (Bobkina \& Stefanova, 2016, p. 685). 


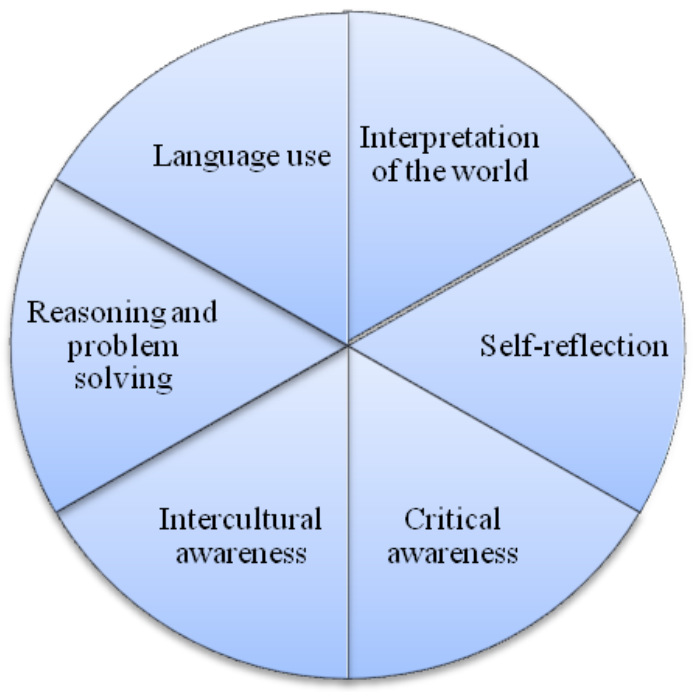

Figure 1. Critical thinking skills required to work with literary texts (Adapted from Bobkina \& Stefanova, 2016)

The authors have also designed a series of activities to put the model into practice. To this end, the theoretical framework has been translated into a pedagogical model based on the ideas of multiliteracies pedagogy (Kalantzis \& Cope, 2000; Cope \& Kalantzis, 2009; 2013; 2015) in an attempt to address the full range of literacies (see Figure 2).
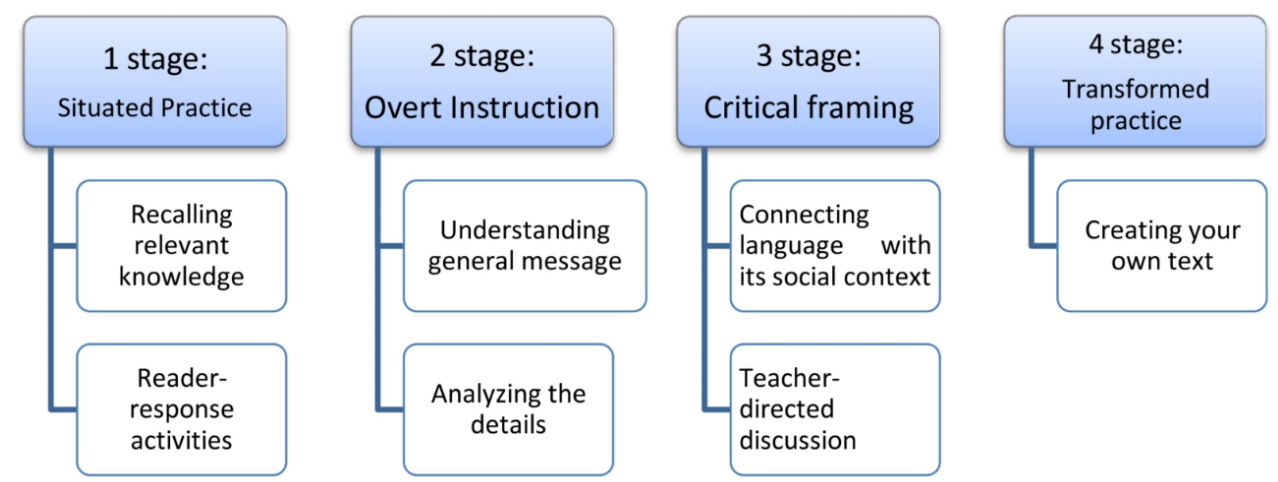

Figure 2. Pedagogical application of the model of teaching critical thinking skills through literature (Bobkina \& Stefanova, 2016)

The four-stage process, represented in Figure 2, describes a learning process, suitable for the application of the model of teaching critical thinking skills. The first stage comprises a set of pre-reading activities aiming to activate students' schemata of the topic. Students read the text and share their ideas, feelings, and experiences. The second stage deals with the general comprehension of the text, conducted through general comprehension questions and discussion activities. The close reading of the text provided in this stage helps students to understand the inner logic of the literary text. The third stage deals with the students' conscious attention to relationships between linguistic forms and sociocultural contexts. The writer's attitude, point of view, and intentions are explored through the analysis of the lexical and structural choices of the text. Finally, the fourth stage includes the creation of students' own texts, that may include reshaping the original texts within the same mode or shifting from one mode to another.

\section{Language and literacy education from a transnational perspective}

Our proposal seeks to address both language teaching and literacy education from a transnational perspective in an attempt to account for the complex phenomena that have emerged as a result of globalization. There has been a long debate over the use of terms such as "global", "cosmopolitan", or "transnational" to refer to phenomena influenced by and concerned with new paradigms that reflect the cross-boundary flows of people, ideas, and cultural production. The field of postcolonial studies and its interest in exposing discrimination and oppression on the basis of race, ethnicity, class, and gender has contributed greatly to our understanding of the concept of "difference" and has raised our awareness of the need to develop students' critical thinking skills that enable them to become active agents of social change. In the foreword to Teaching Transnational Youth, Randy Bomer (2015) calls thinking in terms of difference "deficit thinking" and claims that it legitimates stratification and oppression (p. x). Along the same line, Allison Skerrett (2015), whose main concern is the student diversity in schooling environments, points to the growing number of literacy researchers who connect language and literacy practices and foregrounds "transnationlism in literacy education" (p. xi). This recent trend of connecting language and literacy education from a transnational perspective is one of the reasons for our choice of Caryl Phillips's novel The Lost Child (2015) for our didactic proposal. 
In approaching the idea of working with transnational fiction to develop critical thinking in the EFL classroom, we draw on Stephen Clingman's understanding of the concept. For him, transnational fiction "does not necessarily come from writer who travel or books that do", but "what makes fiction transnational are questions of form" (2012, p. 10, italics in original). Clingman views the question of form at two levels: (1) "recognizable formal characteristics", such as "their structures of time and space, and a set of figurations and properties, whose logic will become clear, of metonymy, chiasmus, constellation, and much else besides" and (2) "form as what informs these novels and produces their visible patterns", i.e. "form becomes content — a way of being and seeing" (2012, p. 10-11, italics in original). One of the authors Clingman examines to illustrate his approach is Caryl Phillips.

It is not our intention to discuss the concept of "transnational fiction", but to explore its didactic potential for developing critical thinking skills. In this sense, our perspective aligns with the second level Clingman identifies, i.e. the transnational as "a way of being and seeing". We view the didactic dimension of transnational fiction as an interpretative frame. From this standpoint, Caryl Phillips's The lost Child is suitable for the implementation of the model also because of the wide range of topics it examines, which include, but are not limited to: immigration, discrimination, home, weak or absent parents, and bullying.

\section{Research questions}

The present study addresses the question of the effectiveness of the model of teaching critical thinking skills through literature in an EFL classroom. The questions addressed in this study are: (1) how do students and their teacher perceive the effectiveness of the model of teaching critical thinking skills to improve students' skills to think critically as well as their grasp of the foreign language?, and (2) how effective in operational terms are the evaluation instruments, in particular, the Assessment Criteria Grid and the Assessment Checklists for students and teachers?

\section{Methodology \\ 5.1 Participants}

The present investigation relies on a case study approach, which includes both qualitative and quantitative techniques. It focused on a selected group of students studying English as a foreign language. The experiment involved 21 Administration and Finance degree students from a Centre for Technical and Vocational Education, a bilingual state school located in the south of Castilla-La Mancha region in Spain. The average age of the group is about twenty. Their English level ranges from B1 to B2, as classified by the CEFR (Council of Europe, 2001). Most of the students did not have any previous experience of working with literary texts in the English classroom and the textbook used in the EFL course does not include any material or activities that display the six dimensions of the model of teaching critical thinking skills mentioned above. The materials they use in class focus on teaching of specific language content, mostly related to administration and finance.

\subsection{Materials}

Materials included a pedagogical proposal based on the combination of reader-centered critical reading approach and the critical pedagogy approach was developed by the authors. To its end, a series of activities were designed based on the strategies endorsed by both theories and were sequenced following the major dimensions of literacy pedagogy: situated practice, overt instruction, critical framing and transformed practice (Cope \& Kalantzis, 2015).

Caryl Phillips's novel The Lost Child, the work we chose for the design of the didactic material, is set in Britain in the 1960s. It revolves around the story of Monica and her two young sons Ben and Tommy, which is framed by the author's reworked version of orphaned, found, and adopted Heathcliff from Emily Brontë's Wuthering Heights (1847). After dropping out of Oxford to marry an African-Caribbean student, Monica becomes alienated from her parents. Abandoned by her husband and poverty stricken, she makes an effort to raise her children alone, but gradually succumbs to depression and the two boys are taken in by a foster family. Tommy "becomes the target of psychological and physical bullying" (Stefanova, 2016, p. 98) at school and when the two boys are sent to a camp in Silverdale. His older brother, Ben, tries to protect him, however he feels he "should have done more", a feeling that keeps him awake for years after Tommy's mysterious disappearance (Phillips, p. 189).

The class work focused on the chapter called "Childhood". Our choice of the literary extract is justified by two main reasons: (1) it is divided into numerous short fragments, which allows for intensive reading activities, and (2) in it, the older brother, Ben, describes his personal experience of how he witnessed his mother's struggle with depression and his younger brother's being humiliated, which enables the students to connect the literary text to real-life problems.

In what follows, we provide a series of the activities carried out by the selected group of students in the EFL classroom.

\section{Stage I: Situated Practice: Experiencing the new}

\section{Recalling relevant knowledge}

1. Students are shown images related to immigration, taken from British newspapers and stripped of their captions. Key question: What is the first thing you think of when you see these pictures?

Students watch a short video called "What is the first thing you think of when you hear the word 'immigrant'?", in which Americans comment on what comes to their mind first at hearing the word. They are encouraged to compare their answers to the answers of the people interviewed in the video. 
2. Students work in pairs to identify the main topics in Phillips's fiction. The teacher provides each pair with a book review of one of the novels previous to The Lost Child, e.g. the 325-word book review of The Final Passage (1985), published in the American magazine Kirkus. Students share their ideas in class.

3. The teacher presents the book title and the chapter titles and asks students what they expect, taking into account Phillips's background and the main themes of his fictional works. Subsequently, the teacher offers a summary of the novel and the class moves on to explore the chapter called "Childhood".

\section{Reader-response activities}

4. The chapter "Childhood" is divided into sixteen short fragments. The title of each fragment is the title of a song, e.g. "Hey Jude" by The Beatles. Students work in pairs. The teacher assigns each pair a different fragment. Students read the text and listen to the song after which the fragment is named. They are asked to change the title of the text, choosing another song to reflect the essence of that fragment.

5. Students discuss the feelings of the older brother, who is the narrator in this case. How does he feel and react about his mother's illness, his foster family, their trip to the camp in Silverdale, or when his history teacher puts him on the list for Oxford and Cambridge. In what way, if any, Ben's experiences are similar to students of his age in our times? How are they different? What/Who gives him strength to overcome difficulties?

\section{Stage II: Overt Instruction: Conceptualising with theory}

\section{Understanding general message}

Students read the fragments again and answer the following general comprehension questions:

- What is the prevailing mood in both the text and the music?

- What is the main idea of the fragment they have read?

- Students take turns to provide a one-sentence summary of the fragment they have read. The rest of the class write down the sixteen sentences that correspond to the sixteen fragments, thus building a summary of the chapter.

- The boys' home environment is not supportive. The meaning of "home" is an essential theme in Phillips's fiction. What does "home" mean to Ben and Tommy? What does "home" mean to the students?

- Tommy refuses to speak about the bullying. Why do you think he did not speak to his older brother about it?

- What is your overall impression? Would you say the chapter "Childhood" is pessimistic or optimistic?

\section{Analysing the language details}

1. Identify the words and expressions Phillips uses to describe Ben's feelings and divide them into positive and negative. Make a list of ten adjectives with positive and ten adjectives with negative connotations.

2. Examine the grammatical structure of the text. What narrative tenses does the author use to reflect Ben's memories? What is the effect on the reader? Find examples of Past Simple, Past Progressive, and Past Perfect Tense. Find examples of the expressions used to and would and comment on the difference between them.

3. Students make five sentences remembering their childhood, using used to and would.

\section{Stage III: Critical framing: Analysing critically}

\section{Connecting language with its social context.}

1. Identify five adjectives and five verbs used by the author to describe Ben and Tommy's home. Analyse the emotions they evoke.

2. Identify and analyse Ben's references to his younger brother Tommy. How do we know Tommy was being bullied? How does Ben feel about it?

3. Phillips does not describe the acts of bullying. He chooses to describe the impact they have on the boy. Why do you think the author employs this narrative technique?

4. Bullying is often defined as a relationship with an imbalance of power. Can you think of an example of relationship with an imbalance of power not between individuals, but between social groups? What is the effect on the weaker group?

5. What makes Tommy more vulnerable than his brother at school and at the camp? What makes a social group vulnerable? In what way can education contribute to the integration of vulnerable individuals or groups?

\section{Stage IV: Transformed practice: Applying creatively}

\section{Creating your own texts}

1. In Philips's novel, no one helps Tommy when he is being bullied at school and in Silverdale. Students re-write the story including a new character, Tommy's new friend, who protects him from the bullies. 
2. Students write a letter of gratitude to a friend who helped them when they most needed it, discerning the meaning of such experience. They have to keep the conventions of an informal letter.

\subsection{Instruments}

To assess the effectiveness of teaching critical thinking skills, Critical Thinking Assessment Criteria Grid (Appendix 1) was elaborated and adapted to be used as pre-test and post-test evaluation instrument by teachers and students. Additionally, Teacher Assessment Checklist (Appendix 2) and Student Self-Assessment Checklist (Appendix 3) were created to facilitate the use of the Assessment Grid. The instruments were designed around the model proposed by Bobkina \& Stefanova (2016) that describes critical thinking process as a set of skills characterised by the following dimensions "the interpretation of the world, self-reflection, intercultural awareness, critical awareness, reasoning and problem-solving, and language use" (p. 685). The Teacher Assessment Checklist and the Student Self-Assessment Checklist describe each of the dimensions depicted in the grid as a list of competence or attainment criteria associated with critical thinking skills. Each dimension is represented as a set of gradable skills and abilities with assigned values from 1 to 4.

\subsection{Procedure}

The study lasted four weeks, from 16 January 2017 to 12 February 2017, and was carried out over six fifty-minute sessions. English was used as medium of instruction.

\section{Week 1}

Two sessions were carried out in the first week on two different days.

In the first session the teacher introduced the students to the concept of critical thinking skills and they discussed the importance of developing the ability to think critically. Students were provided with the Critical Thinking Assessment Criteria Grid (Appendix 1) and were asked to make a list of life situations and experiences to which at least one of the six dimensions in the grid applies. Students were also given the Student Self-Assessment Checklist (Appendix 3) and instructed how to use and relate the two assessment instruments. In the same session the teacher presented the aims, structure, and sequence of the literature-based activities, with special attention to the potential of literary texts to provide opportunities for the development of critical thinking skills. Then, the teacher administered the Self-Assessment Checklist to gather information about the students' perceived level of critical thinking skills.

In the second session, students were engaged in completing the tasks related to Stage 1 (Situated Practice) of the literature-based proposal. They were asked to read the chapter called "Childhood" from Caryl Phillips's novel The Lost Child and start working with the literary text.

\section{Week 2}

Students proceeded to Stage 2 (Overt Instruction). This stage was roughly divided into two parts. Firstly, students were asked to answer some general comprehension questions on the chapter "Childhood", which they had previously read with special emphasis on the concept of "home", which in Phillips's fiction relates to his concern with themes such as identity and belonging. In the second part students were asked to analyse language details and the way they influence meaning construction.

Week 3

Students completed Stage 3 (Critical framing). In this stage students had to analyse the language used by the author critically and connect it with its social context. The session focused on topics such as exclusion, discrimination, and bullying.

Week 4

Two sessions were carried out in the fourth week on two different days. In the first session the students completed the final tasks, which correspond to Stage 4 (Transformed practice). They wrote two texts in different registers to apply creatively what they had learnt.

In the second session the Student Self-Assessment Checklist (Appendix 3) was administered again.

The Teacher Assessment Checklist was administered once, at the end of the study. Each student was evaluated by the teacher based on the activities carried out during the sessions.

\section{Data collection and analysis}

Data collection and analysis focused on the two main agents of the learning process: the students and the teacher. Data was obtained from the previously mentioned checklists, systematised, presented in tables and graphs, and analysed. The study consisted of two parallel lines of data: (1) a comparison of students' pre-test and post-test perception of their own critical thinking skills, and (2) a comparison of students' post-test self-assessment and the teacher's post-test assessment of the students' critical thinking skills. The analysis of the two lines showed the complexity of evaluating the effectiveness of the proposed model. Besides that, several comparisons were made within the same data-set. We opted for a general analysis of students' perceived improvement of their critical thinking skills (Table 3, Figures 3 and 4) and a comparative analysis of the students' post-test self-assessment results and the teacher's assessment of the effectiveness of the model (Table 4, Figures 5, 6, and 7).

Table 1 shows the variation between the students' perceived critical thinking competence before and after having carried out the proposed set of activities. 
Table 1. Students Pre-Test Self and Post-Test Self Assessment Results

\begin{tabular}{|c|c|c|c|c|c|c|c|c|}
\hline \multirow{2}{*}{$\begin{array}{c}\text { Levels } \\
\text { Dimensions }\end{array}$} & \multicolumn{2}{|c|}{ Level 1 - Poor } & \multicolumn{2}{|c|}{$\begin{array}{l}\text { Level } 2 \text { - Below } \\
\text { Satisfactory }\end{array}$} & \multicolumn{2}{|c|}{ Level 3 - Good } & \multicolumn{2}{|c|}{ Level 4 - Excellent } \\
\hline & Pre- & Post- & Pre- & Post- & Pre- & Post- & Pre- & Post- \\
\hline $\begin{array}{l}\text { Interpretation } \\
\text { of the world }\end{array}$ & $0,00 \%$ & $0,00 \%$ & $14,28 \%$ & $0,00 \%$ & $66,67 \%$ & $71,50 \%$ & $19,05 \%$ & $28,57 \%$ \\
\hline Self-Reflection & $0,00 \%$ & $0,00 \%$ & $19,05 \%$ & $0,00 \%$ & $38,09 \%$ & $57,20 \%$ & $42,86 \%$ & $42,86 \%$ \\
\hline $\begin{array}{c}\text { Critical } \\
\text { Awareness }\end{array}$ & $0,00 \%$ & $0,00 \%$ & $19,05 \%$ & $14,29 \%$ & $38,09 \%$ & $71,50 \%$ & $42,86 \%$ & $14,29 \%$ \\
\hline $\begin{array}{l}\text { Intercultural } \\
\text { Awareness }\end{array}$ & $0,00 \%$ & $0,00 \%$ & $9,52 \%$ & $0,00 \%$ & $61,91 \%$ & $71,50 \%$ & $28,57 \%$ & $28,57 \%$ \\
\hline $\begin{array}{l}\text { Reasoning and } \\
\text { Problem } \\
\text { Solving }\end{array}$ & $0,00 \%$ & $0,00 \%$ & $33,33 \%$ & $28,57 \%$ & $52,38 \%$ & $57,20 \%$ & $14,29 \%$ & $14,29 \%$ \\
\hline Language Use & $0,00 \%$ & $0,00 \%$ & $71,50 \%$ & $57,14 \%$ & $18,98 \%$ & $42,90 \%$ & $9,52 \%$ & $0,00 \%$ \\
\hline
\end{tabular}

The results show that all the students perceived their competence in the six dimensions between level 2 (below satisfactory) and level 4 (excellent), before and after the work with the literary text. It is significant that the number of students who considered their level of self-reflection, critical awareness, and intercultural awareness as below satisfactory was reduced to zero, i.e. some students who had low initial expectations gained confidence after working with the text. Although the number of students who perceived their level as below satisfactory in critical awareness and reasoning and problem solving slightly increased, there is still a small percentage whose attitude towards their competence in these two dimensions remains below positive. Overall, it wouldn't be wrong to say that most students saw their competence as good after completing the four phases of the project. It is interesting to note that $42,86 \%$ of the students had very high opinion about their critical awareness competence and in the post-test checklist this percentage dropped to $14,29 \%$. In absolute terms it is a lot lower, however, we interpret it as a positive result, in the sense that the proposed activities made students aware of the need to improve their critical awareness and of the complexity of the concept. In their comments, some of these students mentioned that they had underestimated the value of critical awareness and did not have a clear idea of the breadth and depth of the dimension. The language in use dimension scored lower than the other five dimensions. 9,52\% of the students viewed their language in use competence as excellent in the pre-test checklist, but the post-test results do not seem to have met their expectations, presumably for two main reasons: (1) their assumption was based on the use of English in class activities that do not require critical thinking skills, and (2) the literary text they worked with has a rich repertoire of more nuanced lexical items than those they were familiar with. The same decreasing tendency from pre to post-test results is clearly observed if we compare the figures in levels 3 (good) and 4 (excellent) of critical awareness and language in use. To establish a correlation pattern, a broader scope research must be conducted. However, we could detect that engaging students in a close critical reading that involved understanding of the literary strategies and interpretation of the meaning of language use drew their attention to the need to improve their competence in these two dimensions.

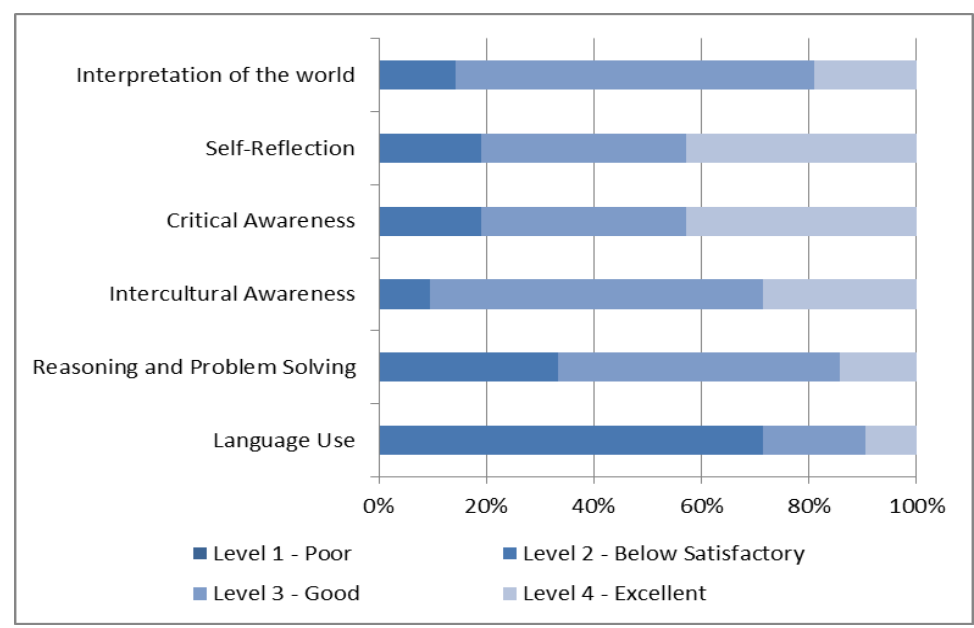

Figure 3. Students Pre-Test Self-Assessment Results 


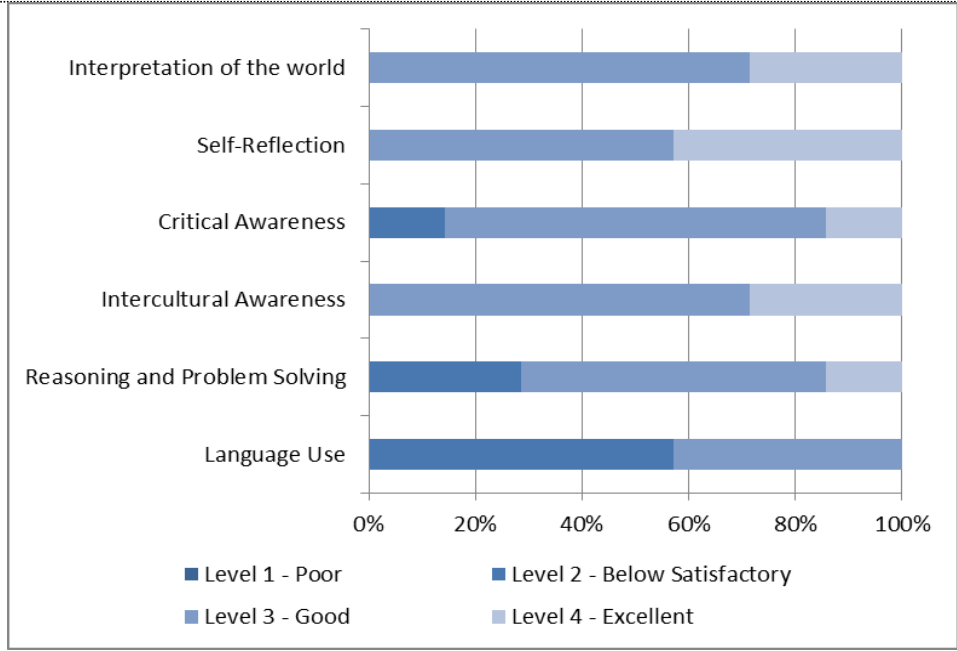

Figure 4. Students Post-Test Assessment Results

As shown in Table 2, students' perceived competence does not fully coincide with the teacher's assessment of their competence attainment after the completion of the series of activities.

Table 2. Students Post-Test Self Assessment Results and Teacher Assessment Results

\begin{tabular}{|c|c|c|c|c|c|c|c|c|}
\hline \multirow{2}{*}{$\begin{array}{c}\text { Levels } \\
\text { Agents / } \\
\text { Dimensions }\end{array}$} & \multicolumn{2}{|c|}{ Level 1 - Poor } & \multicolumn{2}{|c|}{$\begin{array}{l}\text { Level } 2 \text { - Below } \\
\text { Satisfactory }\end{array}$} & \multicolumn{2}{|c|}{ Level 3 - Good } & \multicolumn{2}{|c|}{ Level 4 - Excellent } \\
\hline & Students & Teacher & Students & Teacher & Students & Teacher & Students & Teacher \\
\hline $\begin{array}{l}\text { Interpretation } \\
\text { of the world }\end{array}$ & $0,00 \%$ & $0,00 \%$ & $0,00 \%$ & $0,00 \%$ & $71,50 \%$ & $14,29 \%$ & $28,57 \%$ & $85,71 \%$ \\
\hline Self-Reflection & $0,00 \%$ & $0,00 \%$ & $0,00 \%$ & $14,29 \%$ & $57,20 \%$ & $0,00 \%$ & $42,86 \%$ & $85,71 \%$ \\
\hline $\begin{array}{c}\text { Critical } \\
\text { Awareness }\end{array}$ & $0,00 \%$ & $14,29 \%$ & $14,29 \%$ & $42,86 \%$ & $71,50 \%$ & $42,86 \%$ & $14,29 \%$ & $0,00 \%$ \\
\hline $\begin{array}{c}\text { Intercultural } \\
\text { Awareness }\end{array}$ & $0,00 \%$ & $0,00 \%$ & $0,00 \%$ & $14,29 \%$ & $71,50 \%$ & $0,00 \%$ & $28,57 \%$ & $85,71 \%$ \\
\hline $\begin{array}{l}\text { Reasoning and } \\
\text { Problem } \\
\text { Solving }\end{array}$ & $0,00 \%$ & $14,29 \%$ & $28,57 \%$ & $0,00 \%$ & $57,20 \%$ & $85,71 \%$ & $14,29 \%$ & $0,00 \%$ \\
\hline Language Use & $0,00 \%$ & $14,29 \%$ & $57,14 \%$ & $42,86 \%$ & $42,90 \%$ & $42,86 \%$ & $0,00 \%$ & $0,00 \%$ \\
\hline
\end{tabular}

The findings reveal that the general trend in students' perception of their improvement correlated sufficiently well with the teacher's evaluation of their achievements in two aspects: critical awareness and language use. The low performance in language use is also due to the fact that to reason critically, express and support their arguments on topics like social inequality, depression, or bullying, students were challenged to involve in argumentation and learn or master devises used in argumentative discourse. Although vocabulary wasn't a serious obstacle, the difficulties second language learners may experience with certain discourse-organising words carry important information about the assessment results. Similar figures in the students' post-test checklist and the teachers checklist in the two dimensions mentioned above suggest that students had a realistic perception of their performance in these particular processes, but also that they understood well the meaning of these dimensions. For the teacher, $85,71 \%$ of the students demonstrate good (performance level 3) reasoning and problem solving skills and although the students' survey differs slightly, their score on this dimension is highly satisfactory. The model has proved effective in enhancing a dimension which is widely applicable to other educational areas and has a strong positive direct effect on students' ability to find an adequate solution to real-world problems.

When considered jointly, students' self-assessment results and the teacher's assessment results (see Figures 5, 6, and 7) on interpretation of the world, self-reflection, and intercultural awareness display a similar pattern, characterised by a significant disagreement between the results obtained from the students' checklist and from the teacher's checklist, in particular, in performance levels 3 and 4, e.g. on interpretation of the world $28,57 \%$ of the students evaluated their achievement level as 4 (excellent) and the teacher gave $85,71 \%$ of the students an excellent mark. In an attempt to shed light on this disagreement, we analysed data from a slightly different perspective and focused on the highest score for both students and the teacher. It becomes clear that this difference does not affect the outcome of the implementation of the model, which for these three dimensions ranged from level 3 (self-perception scores) to level 4 (the teacher's scores), indicating in a highly favourable attitude towards this model of teaching critical thinking skills and the series of 
activities the students carried out in class. There were many comments in the students' checklists on a very important outcome of the implementation of our proposal, which was not explicitly included among the objectives of the model, i.e. the motivational aspect of the learning process. Students commented that thought-provoking questions and activities motivated them to search for further information about the topics discussed in class. Some of them commented that they would like to read some other works by the same author and that the proposal had awakened their interest in transnational literature. They also admitted that exploring and discussing the fictional text in groups not only helped them to understand better current social phenomena such as immigration, but also helped them gain self-knowledge and recognise their strengths and weaknesses, which is why in their checklist $42,86 \%$ of the students marked their own performance in self-reflection as excellent.

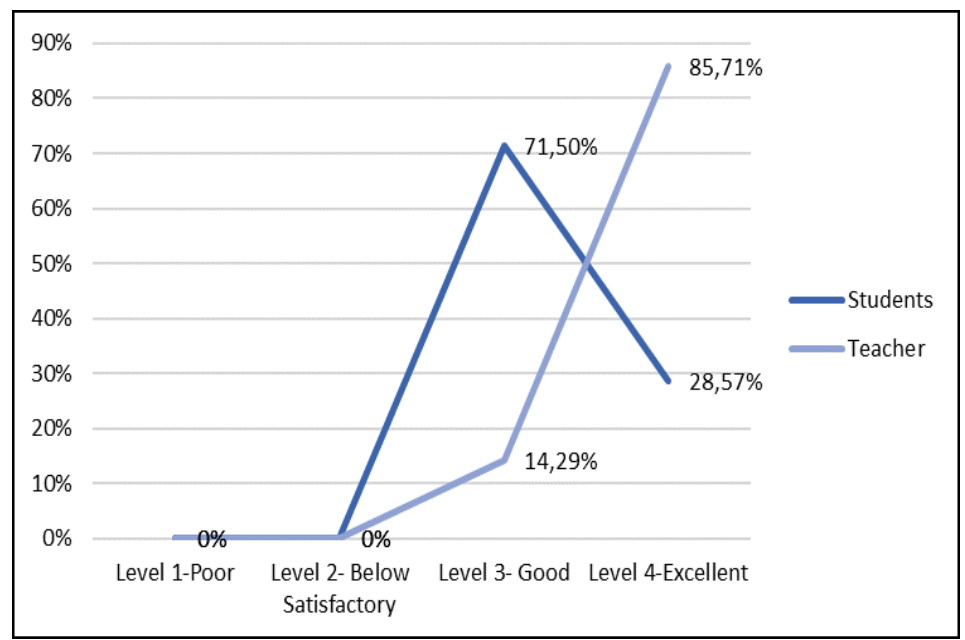

Figure 5. Interpretation of the world

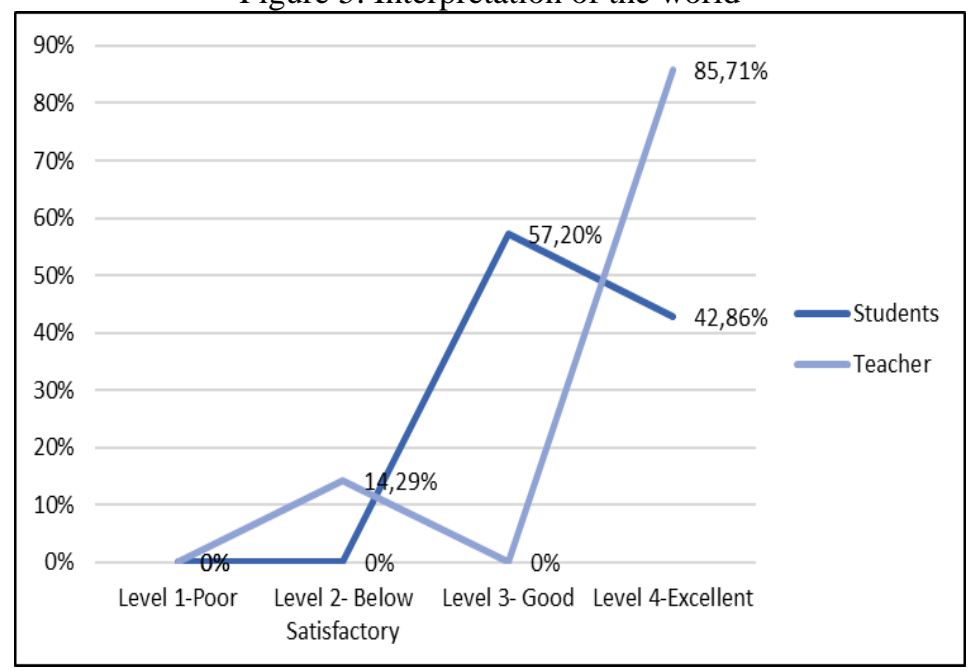

Figure 6. Self-Reflection

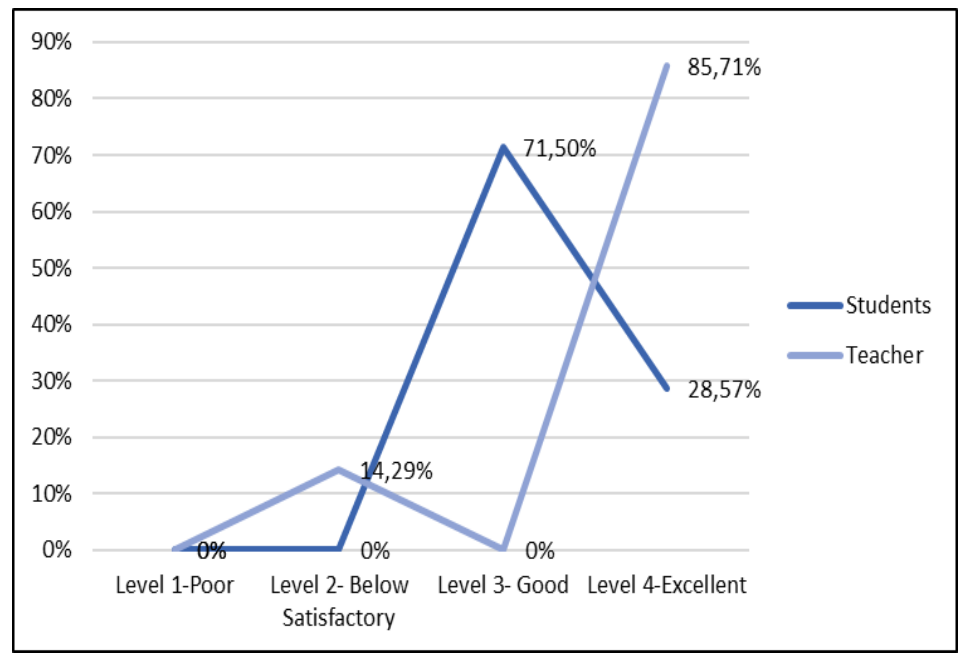

Figure 7. Intercultural Awareness

\section{Conclusions and pedagogical implications}

This study of the effectiveness of teaching critical thinking skills through literature in an EFL classroom in Spain provides valuable data about the benefits and difficulties in implementing the model on which the investigation is 
based. The analysis of the data reveals the great potential of working with a literary text in the English classroom to foster critical thinking skills and opens up the possibility for a major goal: design and implement a long-term project, that extends over at least a full school year, in order to maximize the effects of the model and develop suitable tools teachers can use on a daily basis.

Considering the first research question: how do students and their teacher perceive the effectiveness of the model of teaching critical thinking skills to improve students' skills to think critically as well as their grasp of the foreign language, the findings demonstrate that both students and their teacher perceive the model as highly effective. The main constraint of this study is related to the relatively short period of time for the implementation of the proposal. While students reported increased motivation and higher awareness about the nuances in word meanings, the research data does not provide the required evidence about the positive perception of students' grasp of the foreign language, which implies that a further detailed investigation is necessary to validate our premise that reasoning, discussing, and relating a literary text with topic relevant to the students improves the perception of their proficiency of the foreign language.

With regard to the second research question, how effective in operational terms are the evaluation instruments, in particular, the Assessment Criteria Grid and the Assessment Checklists for students and teachers, the study concludes that self-assessment as an integral part of the model and the 'toolkit' and its scale of descriptors allow for the correct evaluation of the six dimensions of the model and contrastive analysis of the results. An unexpected highly positive impact of the students' understanding of the criteria included in the assessment tools and the opportunity that working with the descriptors provides for reflecting on the meaning of the concept "critical thinking skills" sets the pace for investigating and designing a supplementary pre-implementation stage, in which both students and teachers receive explicit instruction into the principles of critical thinking.

The study sets the agenda for future research in areas such as the need to adapt the descriptors to the students' age, in case the instructor intends to implement the model with young learners, or the creation of practical guides that teachers can use on a daily basis. The choice of the literary work is an important element in the implementation of our proposal, hence the next step would be to establish the criteria for the selection of a literary text. Finally, to ensure the success of the model it is desirable to extend it over a full school year and strengthen its compatibility with the material or textbook the teacher uses for his course.

\section{References}

Aliakbari, M., \& Faraji, E. (2011). Basic principles of critical pedagogy. Second international conference on humanities, historical and social sciences. IPEDR,17, 77-85.

Alvarez, Z., Calvete, M. \& Sarasa, M. (2012). Integrating critical pedagogy theory and practice: classroom experiences in Argentinean EFL teacher education. Journal for Educators, Teachers and Trainers, 3, 60-71.

Bahadur Rana, L. (2012). Critical thinking in EFL classroom. Nelta Choutari. Retrieved from https://neltachoutari.wordpress.com/.

Benesch, S. (Ed.). (2009). Critical English for Academic Purposes. Journal of English for Academic Purposes,8 (2), 81 85.

Bobkina, J., Dominguez Romero, E. (2014). The use of literature and literary texts in the EFL classroom: Between consensus and controversy. International Journal of Applied Linguistics \& English Literature, 3(2), 248-260.

Bobkina, J, Stefanova, S. (2016). Literature and critical literacy pedagogy in the EFL classroom: Towards a model of teaching critical thinking skills. Studies in Second Language Learning and Teaching, 6 (4),677-696.

Braun, N. ( 2004). Critical Thinking in the Business Curriculum. Journal of Education for Business, 79, $232-236$.

Brunt, B. A. (2005). Critical thinking in nursing: An integrated review. Journal of Continuing Education in Nursing, 36 , 60-67.

Cazden, C., Cope, B., Fairclough, N., Gee, J., et al. (1996). A pedagogy of multiliteracies: Designing social futures. Harvard Educational Review, 66 (1), 60-89.

Clingman, S., (2012). The Grammar of Identity: Transnational Fiction and the Nature of Boundary. Oxford: Oxford University Press.

Cope, B. \& Kalantzis, M. (2009). Multiliteracies: New Literacies, New Learning. Pedagogies: An International Journal, 4, 164-195.

Cope, B. \& Kalantzis, M. (2013). "Multiliteracies": New Literacies, New Learning. In Hawkins, M.R. (Ed.) Framing Languages and Literacies: Socially Situated Views and Perspectives (pp. 105-135). New York: Routledge.

Cope, B. \& Kalantzis, M. (2015). The Things You Do to Know: An Introduction to the Pedagogy of Multiliteracies. In B. Cope \& M. Kalantzis (Eds.), A Pedagogy of Multiliteracies: Learning by Design (pp.1-36). London: Palgrave.

Council of Europe (2001). Common European Framework of Reference for Languages: Learning, Teaching, Assessment. Cambridge: Cambridge University Press.

Crookes, G. (2010). The practicality and relevance of second language critical pedagogy. Language Teaching,43(3), 333-348.

Curtis, A., \& Romney, M. (Eds.). (2006). Color, race, and English language teaching. Mahwah, NJ: Lawrence Erlbaum. 
Degener, S. (2001). Making sense of critical pedagogy in adult literacy education. In J. Comings, B. Garner, \& C. Smith (Eds.), Review of adult learning and literacy (pp. 26-62).San Francisco: Jossey-Bass.

Duncan-Andrade, J. M. R., \& Morrell, E. (2008). The art of critical pedagogy: Possibilities for moving from theory to practice in urban schools. New York: Peter Lang.

Egan, K. (2005). An imaginative approach to teaching. San Francisco, CA: Jossey-Bass.

Facione, P. A. (2007). Critical thinking: What it is and why it counts. Milbrae, CA: The California Academic Press.

Fernandez de Caleya, M., Bobkina, J., Sarto, Martes, P. (2012). The use of literature as an advanced technique for teaching English in the EFL/ESL classroom. Educación y Futuro, 27, 217-239.

Fisher, A. (2001). Critical thinking: An introduction. Cambridge: Cambridge University Press.

Gee, J. (1996). Social linguistics and literacies: Ideology in discourses. London, England: Taylor \& Francis Ltd.

Ghosn, I. (2002). Four good reasons to use literature in primary school ELT, ELT Journal, 2(56), 172-179.

Guerin, J., Labor, E., .Morgan, L., Reesman J., \& Willingham, J. A. (2005). Handbook of critical approaches to literature. New York: Oxford University Press.

Izadinia, M. (2011). Incorporating the principles of critical pedagogy into a teacher efficacy measure. English Language Teaching,4(2), 138-150.

Janks, H. (2010). Literacy and power. New York/London: Routledge.

Kalantzis, M., \& Cope, B. (2000). A multiliteracies pedagogy: A pedagogical supplement. In B. Cope \& M. Kalantzis (Eds.), for the New London Group, Multiliteracies: Literacy learning and the design of social futures (pp.239-248). London and New York: Routledge.

Klaczynski, P. A. (2001). Framing effects on adolescent task representations, analytic and heuristic processing, and decision making: Implications for the normative/descriptive gap. Journal of Applied Developmental Psychology, 22, 289-309.

Khatib, M., Marefat, M. \& Ahmadi,M. (2012). Enhancing critical thinking abilities in EFL classrooms:

Through written and audiotaped dialogue journals. Humanity \& Social Sciences Journal, 7 (1), 33-45.

Langer, J. (1997). Literacy acquisition through literature. Journal of Adolescent and Adult Literacy, 40, 602-614.

Lazere, D. (1987). Critical thinking in college English studies, ERIC Digest, Retrieved from http://www.eric.ed.gov/ERICWebPortal/contentdelivery/servlet/ERICServlet?accno=ED284275.

Moreno-López, I. (2004). Critical pedagogy in the Spanish language classroom: A liberation process. Taboo, 8 (1), 7784.

Nelson, C. D. (2008). Sexual identities in English language classrooms. New York: Routledge.

Norton, B., \& Toohey, K. (2004). Critical pedagogies and language learning. Cambridge: Cambridge University Press.

Ohara, Y., Saft, S., \& Crookes, G. (2001). Toward a feminist critical pedagogy in a beginning Japanese as a foreign language class. Japanese Language and Literature: Journal of the Association of Teachers of Japanese, 35(2), 105-133.

Pennycook, A. (2001). Critical applied linguistic: A critical introduction. Mahwah, NJ Lawrence Erlbaum.

Pineda Báez, C. (2004). Critical thinking in the EFL classroom: The search for a pedagogical alternative to improve English learning. Ikala, 9 (15), 45-80.

Phillips, C. (2015). The Lost Child. London: Oneworld.

Qing, X. (2013). Fostering critical thinking competence in EFL classroom. Studies in Literature and Language, 7 (1), 69.

Riasati, M., \& Mollaei, F. (2012). Critical pedagogy and language learning. International Journal of Humanities and Social Science, 21(2), 223-229.

Sivasubramaniam, S. (2006). Promoting the prevalence of literature in the practice of foreign and second language education: issues and insights. The Asian EFL Journal Quarterly, 8(4), 254- 273.

Skerrett, A. (2015). Teaching transnational youth: Literacy and education in a changing world. New York: Teachers College Press.

Stefanova, S. (2016). [Review of the book The Lost Child by C. Phillips]. Wasafiri, 88 Winter 2016, 97-98.

Van, T. (2009). The relevance of literary analysis to teaching literature in the EFL classroom, English Teaching Forum, $3,2-9$.

Willingham, D. T. (2007). Critical thinking. American Educator, Summer 2007, 8-18.

Yaqoob, M. (2011). Reader and text: Literary theory and teaching of literature in the twenty first century. International Conference on Languages, Literature and Linguistics IPEDR , 26, 511-515. 


\section{Developing Critical Thinking Skills through Literature: Assessment Criteria Grid}

\begin{tabular}{|c|c|c|c|c|}
\hline $\begin{array}{l}\text { Dimensions of } \\
\text { Critical Thinking } \\
\text { Skills }\end{array}$ & $\begin{array}{c}1 \text { - Poor } \\
\text { If applicable, consistently does all or } \\
\text { almost all of the following }\end{array}$ & $\begin{array}{l}\text { 2- Below Satisfactory } \\
\text { If applicable, consistently does } \\
\text { most or many of the following }\end{array}$ & $\begin{array}{l}\text { 3 - Good } \\
\text { If applicable, consistently does } \\
\text { most or many of the following }\end{array}$ & $\begin{array}{c}\text { 4 - Excellent } \\
\text { If applicable, consistently does all or } \\
\text { almost all of the following }\end{array}$ \\
\hline $\begin{array}{l}\text { Interpretation of } \\
\text { the world }\end{array}$ & $\begin{array}{l}\text {--Fails to demonstrate the ability to } \\
\text { connect, interpret and discern the } \\
\text { intricacies of the world depicted in the } \\
\text { literary work. } \\
\text {--Fails to define clearly the issue or } \\
\text { problem depicted in the literary work. } \\
\text {--Fails to understand and interpret the } \\
\text { depth and breadth of the problem. } \\
\text {-- Fails to relate issues or problems } \\
\text { depicted in the literary text to the world } \\
\text { he lives in, hence his ability to interpret } \\
\text { his own world remains unchanged. }\end{array}$ & $\begin{array}{l}\text {--Demonstrates limited ability to } \\
\text { connect, interpret and discern the } \\
\text { intricacies of the world depicted in } \\
\text { the literary work. } \\
\text {--Poorly defines the issue or } \\
\text { problem depicted in the literary } \\
\text { work. } \\
\text {--Has serious difficulties in } \\
\text { understanding and interpreting the } \\
\text { depth and breadth of the problem. } \\
\text {-- Cannot adequately relate issues } \\
\text { or problems depicted in the literary } \\
\text { text to the world he lives in, hence } \\
\text { his ability to interpret his own } \\
\text { world does not improve noticeably. }\end{array}$ & $\begin{array}{l}\text {--Demonstrates sufficient ability to } \\
\text { connect, interpret and discern the } \\
\text { intricacies of the world depicted in } \\
\text { the literary work. } \\
\text {--Adequately defines the issue or } \\
\text { problem depicted in the literary } \\
\text { work. } \\
\text {-- Does not fully understand the } \\
\text { depth and breadth of the problem. } \\
\text {--Can adequately relate issues or } \\
\text { problems depicted in the literary } \\
\text { text to the world he lives in, which } \\
\text { opens up possibilities for new } \\
\text { interpretations of his own world. }\end{array}$ & $\begin{array}{l}\text {-- Demonstrates a clear ability to } \\
\text { connect, interpret and discern the } \\
\text { intricacies of the world depicted in the } \\
\text { literary work. } \\
\text {--Accurately defines the issue or } \\
\text { problem depicted in the work. } \\
\text {--Appreciates the depth and breadth of } \\
\text { the problem. } \\
\text {--Can successfully relate issues or } \\
\text { problems depicted in the literary text to } \\
\text { the world he lives in, which helps him } \\
\text { understand his own reality. }\end{array}$ \\
\hline Self-reflection & $\begin{array}{l}\text {-Fails to make connections between the } \\
\text { literary text and one's own experiences } \\
\text { and beliefs. } \\
\text {-Fails to identify and explain the impact } \\
\text { of the text on personal values, beliefs, } \\
\text { styles of communication, and experience. } \\
\text {-Cannot understand one's culture, } \\
\text { personal and cultural biases, experiences, } \\
\text { and beliefs. }\end{array}$ & $\begin{array}{l}\text {-Makes limited connections } \\
\text { between the literary text and one's } \\
\text { own experiences and beliefs. } \\
\text {-Has difficulties in identifying and } \\
\text { explaining the impact of the text on } \\
\text { personal values, beliefs, styles of } \\
\text { communication, and experience. } \\
\text {-Has difficulties in understanding } \\
\text { one's culture, personal and cultural } \\
\text { biases, experiences, and beliefs. }\end{array}$ & $\begin{array}{l}\text {-Makes some connections between } \\
\text { the literary text and one's own } \\
\text { experiences and beliefs. } \\
\text { - Adequately identifies and } \\
\text { explains the impact of the text on } \\
\text { personal values, beliefs, styles of } \\
\text { communication, and experience. } \\
\text {-Demonstrates an adequate } \\
\text { understanding of one's culture, } \\
\text { personal and cultural biases, } \\
\text { experiences, and beliefs. }\end{array}$ & $\begin{array}{l}\text {-Makes clear connections between the } \\
\text { literary text and one's own experiences } \\
\text { and beliefs. } \\
\text {-Identifies and accurately explains the } \\
\text { impact of the text on personal values, } \\
\text { beliefs, styles of communication, and } \\
\text { experience. } \\
\text {-Demonstrates a deep understanding of } \\
\text { one's culture, personal and cultural } \\
\text { biases, experiences, and beliefs. }\end{array}$ \\
\hline $\begin{array}{c}\text { Critical } \\
\text { awareness }\end{array}$ & $\begin{array}{l}\text {--Relies on insufficient, irrelevant, or } \\
\text { unreliable information. } \\
\text {-- Fails to demonstrates the ability to } \\
\text { process data, using critical thinking. } \\
\text {--Fails to identify or hastily dismisses } \\
\text { strong, relevant counter-arguments. }\end{array}$ & $\begin{array}{l}\text {--Gathers some credible, but not } \\
\text { sufficient information; not all of it } \\
\text { is irrelevant and is not absorbed via } \\
\text { awareness. } \\
\text {--Demonstrates limited ability to } \\
\text { process data, using critical } \\
\text { thinking. } \\
\text {-- Some strong counter-arguments } \\
\text { may be omitted. }\end{array}$ & $\begin{array}{l}\text {--Gathers sufficient and credible } \\
\text { information and absorbs it via } \\
\text { awareness. } \\
\text {--Demonstrates a satisfactory } \\
\text { ability to process data, using } \\
\text { critical thinking. } \\
\text {-- Includes some information from } \\
\text { opposing views. }\end{array}$ & $\begin{array}{l}\text {--Gathers sufficient, credible, and } \\
\text { relevant information and absorbs it via } \\
\text { awareness. } \\
\text {--Demonstrates an excellent ability to } \\
\text { process data, using critical thinking. } \\
\text {--Includes information that opposes as } \\
\text { well as supports the argued position. }\end{array}$ \\
\hline
\end{tabular}




\begin{tabular}{|c|c|c|c|c|}
\hline $\begin{array}{l}\text { Intercultural } \\
\text { awareness }\end{array}$ & $\begin{array}{l}\text {--Fails to recognize beliefs, values and } \\
\text { customs based on different cultural } \\
\text { assumptions. } \\
\text {-- Misunderstands cultural differences } \\
\text { and is not able to interpret different } \\
\text { cultural behaviours. }\end{array}$ & $\begin{array}{l}\text {--Recognizes some beliefs, values } \\
\text { and customs based on different } \\
\text { cultural assumptions. } \\
\text {-- Identifies and explains some } \\
\text { cultural differences and } \\
\text { behaviours. }\end{array}$ & $\begin{array}{l}\text {--Recognizes beliefs, values and } \\
\text { customs based on different cultural } \\
\text { assumptions. } \\
\text {-- Identifies and explains a variety } \\
\text { of cultural differences and } \\
\text { behaviours. }\end{array}$ & $\begin{array}{l}\text {--Clearly recognizes beliefs, values and } \\
\text { customs based on different cultural } \\
\text { assumptions. } \\
\text {-- Accurately identifies cultural } \\
\text { differences and clearly explains } \\
\text { different cultural behaviours. }\end{array}$ \\
\hline $\begin{array}{l}\text { Reasoning and } \\
\text { problem solving }\end{array}$ & $\begin{array}{l}\text {--Fails to identify and interpret the } \\
\text { author's choices regarding content and } \\
\text { structure. } \\
\text {--Makes illogical, inconsistent } \\
\text { conclusions. } \\
\text {--Ignores significant implications and } \\
\text { consequences of reasoning. } \\
\text {-- Because of its poor quality, reasoning } \\
\text { does not allow the student to solve real- } \\
\text { world problems effectively. }\end{array}$ & $\begin{array}{l}\text {--Identifies some of the choices of } \\
\text { content and structure the author } \\
\text { makes, but has difficulties } \\
\text { interpreting them. } \\
\text {--Has difficulties analyzing each of } \\
\text { the three areas of choice; } \\
\text { interferences are often unclear, } \\
\text { illogical and inconsistent; } \\
\text { conclusions are not always based } \\
\text { on evidence. } \\
\text {--Identifies improbable } \\
\text { implications of reasoning. } \\
\text {-- Reasoning allows the student to } \\
\text { interpret real-world problems } \\
\text { adequately, but not to come up } \\
\text { with a solution. }\end{array}$ & $\begin{array}{l}\text {--Identifies and interprets the } \\
\text { choices of content and structure the } \\
\text { author makes, but not with depth } \\
\text { and precision. } \\
\text {-- Examines each of the areas of } \\
\text { choice with moderate precision, } \\
\text { draws interferences, and arrives at } \\
\text { conclusions based on evidence. } \\
\text {--Identifies the most significant } \\
\text { implications and consequences of } \\
\text { reasoning. } \\
\text {-- Reasoning allows the student to } \\
\text { come up with an adequate solution } \\
\text { to a real-world problem. }\end{array}$ & $\begin{array}{l}\text {--Clearly identifies and interprets the } \\
\text { choices of content and structure the } \\
\text { author makes. } \\
\text {--Accurately examines each of the } \\
\text { areas of choice, draws interferences, } \\
\text { and arrives at conclusions based on } \\
\text { evidence. } \\
\text {--Identifies the most significant } \\
\text { implications and consequences of } \\
\text { reasoning. } \\
\text {-- Reasoning allows the student to } \\
\text { come up with an effective solution to a } \\
\text { real-world problem. }\end{array}$ \\
\hline Language use & $\begin{array}{l}\text {--Fails to identify language tools. } \\
\text {--Makes invalid assumptions regarding } \\
\text { the use of these language tools. }\end{array}$ & $\begin{array}{l}\text {-- Identifies language tools used by } \\
\text { the author, but fails to explain } \\
\text { them. } \\
\text {--The assumptions regarding the } \\
\text { use of language tools are irrelevant } \\
\text { or not clearly stated. }\end{array}$ & $\begin{array}{l}\text {--Adequately identifies language } \\
\text { tools used by the author to } \\
\text { influence our perception of the } \\
\text { text. } \\
\text {--Makes reasonable assumptions } \\
\text { regarding the use of language } \\
\text { tools. }\end{array}$ & $\begin{array}{l}\text {--Accurately identifies language tools } \\
\text { used by the author to influence our } \\
\text { perception of the text. } \\
\text {--Makes consistent and reasonable } \\
\text { assumptions regarding the use of } \\
\text { language tools. }\end{array}$ \\
\hline
\end{tabular}




\section{Developing Critical Thinking Skills through Literature: Teacher Assessment Checklist}

\begin{tabular}{|c|c|c|c|}
\hline $\begin{array}{l}\text { If applicable, } \\
\text { score the } \\
\text { element (1-4) }\end{array}$ & $\begin{array}{l}\text { Dimensions of } \\
\text { critical thinking } \\
\text { skills }\end{array}$ & Assessment Criteria & Comments \\
\hline & $\begin{array}{l}\text { Interpretation of the } \\
\text { world }\end{array}$ & $\begin{array}{l}\text { The student demonstrates a clear ability to connect, interpret and discern the intricacies of the world depicted in } \\
\text { the literary work and can successfully relate issues or problems depicted in the literary text to the world he lives } \\
\text { in, which helps him understand his own reality. }\end{array}$ & \\
\hline & Self-reflection & The student makes clear connections between the literary text and one's own experiences and beliefs. & \\
\hline & Critical awareness & The student demonstrates a clear ability to collect and process data, using critical thinking. & \\
\hline & $\begin{array}{l}\text { Intercultural } \\
\text { awareness }\end{array}$ & The student clearly recognizes a variety of beliefs, values and customs based on different cultural assumptions. & \\
\hline & $\begin{array}{l}\text { Reasoning and } \\
\text { problem solving }\end{array}$ & $\begin{array}{l}\text { The student clearly identifies and interprets the choices of content and structure the author makes, which allows } \\
\text { him to come up with an effective solution to a real-world problem. }\end{array}$ & \\
\hline & Language use & The student accurately identifies language tools used by the author to influence our perception of the text. & \\
\hline Overall score: & & & \\
\hline
\end{tabular}

4 = Excellent. Critical thinking is marked by clarity, accuracy, relevance, depth, and breadth.

3 = Good. Critical thinking is competent and effective, but lacks exemplary precision, depth, and breadth.

2 = Below satisfactory. Critical thinking is often unclear, inaccurate, or/and ineffective.

$1=$ Poor. Critical thinking is unskilled and insufficient. It is marked by imprecision, superficiality, and lack of clarity 


\section{Developing Critical Thinking Skills through Literature: Student Self-Assessment Checklist}

\begin{tabular}{|c|c|c|c|}
\hline $\begin{array}{l}\text { If applicable, } \\
\text { score the } \\
\text { element (1-4) }\end{array}$ & $\begin{array}{l}\text { Dimensions of critical } \\
\text { thinking skills }\end{array}$ & Assessment Criteria & Comments \\
\hline & $\begin{array}{l}\text { Interpretation of the } \\
\text { world }\end{array}$ & $\begin{array}{l}\text { I can connect, interpret and discern the intricacies of the world depicted in the literary work and can } \\
\text { successfully relate issues or problems depicted in the literary text to the world he lives in, which helps me } \\
\text { understand my own reality. }\end{array}$ & \\
\hline & Self-reflection & I can make clear connections between the literary text and my own experiences and beliefs. & \\
\hline & Critical awareness & I can effectively collect and process data, using critical thinking. & \\
\hline & Intercultural awareness & I can clearly recognise a variety of beliefs, values and customs based on different cultural assumptions. & \\
\hline & $\begin{array}{l}\text { Reasoning and problem } \\
\text { solving }\end{array}$ & $\begin{array}{l}\text { I can clearly identify and interpret the choices of content and structure the author makes, which allows me } \\
\text { to come up with an effective solution to a real-world problem. }\end{array}$ & \\
\hline & Language use & I can accurately identify language tools used by the author to influence our perception of the text. & \\
\hline Overall score: & & & \\
\hline
\end{tabular}

$4=$ Excellent. Critical thinking is marked by clarity, accuracy, relevance, depth, and breadth.

$3=$ Good. Critical thinking is competent and effective, but lacks exemplary precision, depth, and breadth.

$2=$ Below satisfactory. Critical thinking is often unclear, inaccurate, or/and ineffective.

$1=$ Poor. Critical thinking is unskilled and insufficient. It is marked by imprecision, superficiality, and lack of clarity. 